\title{
The cellular localization of chorionic somatomammotrophin in ovine chorion*
}

\author{
Jacqueline A. Carnegie ††, J. S. D. Chan§, M. E. McCullył. \\ H. A. Robertson $\dagger$ and H. G. Friesen $\S$ \\ $\dagger$ Animal Research Centre, Ottawa, Canada K1A OC6; $\ddagger$ Department of Biology, \\ Carleton University, Ottawa, Canada K1S 5B6, and \$Department of Physiology, \\ University of Manitoba, Winnipeg, Canada R3E OW3
}

\begin{abstract}
Summary. Sections of Days 12 to 55 sheep chorion, embedded at low temperature in glycol methacrylate, were exposed to rabbit anti-ovine chorionic somatomammotrophin (oCS) to ascertain the distribution of oCS. This hormone was first detectable on Day 14, when the cytoplasm of each chorionic cell displayed a low level of fluorescence surrounding droplets which were shown to be lipid containing. At this time, all chorionic cells were uninucleate. By Day 28, binucleate chorionic cells had appeared but showed no binding of the oCS antiserum which was confined to a significant proportion of the uninucleate chorionic cells surrounding lipid droplets, as at Day 14. The same pattern of hormone distribution, although with reduced fluorescence intensity, was observed on Day 55; fluorescence indicative of antibody binding was seen only in some of the uninucleate chorionic cells. Hence, oCS was detected in chorionic tissue before the differentiation of binucleate cells (Day 14) and, at all stages, it was confined to the cytoplasm of specific uninucleate chorionic cells in close association with lipid droplets.
\end{abstract}

\section{Introduction}

The presence of an extra-hypophysial luteotrophin in the pregnant ewe was first proposed by Denamur \& Martinet (1961) following the observation that luteal function was maintained in ewes hypophysectomized after Day 50. Forsyth (1972), using a co-culture system of goat chorion and explants of mouse mammary gland, demonstrated that a lactogen was synthesized by goat chorionic tissue. Kelly, Robertson \& Friesen (1974), using a rabbit mammary gland receptor assay, showed the presence of a lactogenic factor, which was not pituitary prolactin, in sheep throughout pregnancy. Since then, ovine placental lactogen, or ovine chorionic somatomammotrophin (oCS), as it is now called, has been isolated and purified and its abilities to promote growth and casein synthesis are well established (Handwerger, Maurer, Barrett, Hurley \& Fellows, 1974; Martal \& Djiane, 1975; Chan, Robertson \& Friesen, 1976; Fellows, Bolander, Hurley \& Handwerger, 1976; Handwerger et al., 1976; Hurley, Grissom, Handwerger \& Fellows, 1977a; Hurley, Handwerger \& Fellows, 1977b; Chan et al., 1978a, b; Reddy \& Watkins, 1978a).

The binding of labelled anti-oCS serum to sections of Day-16 sheep chorionic tissue (Carnegie, Chan, Robertson, Friesen \& McCully, 1977) has been confirmed, although with variations in precise cellular location of the hormone (Martal, Djiane \& Dubois, 1977; Reddy \&

* Requests for reprints to Dr J. A. Carnegie, Animal Research Center, Ottawa, Canada K1A 0C6. 
Watkins, 1978b; Carnegie, McCully \& Robertson, 1980; Watkins \& Reddy, 1980). The present paper is an extension of earlier work (Carnegie et al., 1977, 1980) in an effort to resolve the question of cellular localization of oCS, particularly regarding its alleged association with binucleate chorionic cells (Martal et al., 1977; Reddy \& Watkins, 1978b; Watkins \& Reddy, 1980).

\section{Materials and Methods}

Many reports dealing with immunolocalization are open to the criticism that preparation of the tissue for microscopy may affect the structure of the protein being investigated (Pearse, 1980). Accordingly, to preserve the antigenic character of the oCS molecule, fixation in $3 \%$ glutaraldehyde at $0^{\circ} \mathrm{C}$ was for $0.5 \mathrm{~h}$ only. This was followed by dehydration and embedding at $-20^{\circ} \mathrm{C}$ in glycol methacrylate (Carnegie et al., 1980), a procedure which has been used successfully to preserve the activity of a number of tissue enzymes (Ashford, Allaway \& McCully, 1972).

\section{Animals}

Crossbred ewes ( 9 for microscopy and 16 for assay of oCS) were synchronized and induced to ovulate with a combination of fluorogestone acetate-impregnated vaginal pessaries (Chrono-gest: Intervet, Angers 49024, France) and PMSG. Following sponge removal, the ewes were run with fertile rams fitted with marking harnesses and checked for mating twice per day. The day of first marking was denoted as Day 0.

\section{Collection and fixation of tissue}

Ewes were slaughtered at Days 12,14 and 16 of gestation. The uteri were immediately removed and flushed with phosphate-buffered saline (PBS), $\mathrm{pH} \mathrm{7.4,} \mathrm{to} \mathrm{obtain} \mathrm{the} \mathrm{products} \mathrm{of}$ conception. At Day 12, the entire blastocyst was transferred to ice-cold, $3 \%$ glutaraldehyde (Polysciences) in 0.1 M-Sörenson's buffer, pH 6.8 (Lillie, 1965) with a Pasteur pipette, while at the two later stages, pieces of chorionic membrane, about $2 \times 2 \mathrm{~mm}$, were cut and placed in the fixative. All tissues were fixed for $0.5 \mathrm{~h}$, thoroughly washed in Sörenson's buffer, dehydrated through a graded glycol methacrylate/water series and low-temperature embedded in glycol methacrylate (Carnegie et al., 1980).

At Days 28 and 55, pieces of tissue were taken from the junction of fetal chorion and

\section{PLATE 1}

All figures show tissue which was treated with Schiff's reagent (reddish background fluorescence) before antibody incubation (green rings of fluorescence indicate sites of antibody binding). The orientation is the same for Figs 1-3: the embryo is to the right and the maternal uterine tissue to the left.

Fig. 1. Day-14 chorion incubated for localization of oCS. Cytoplasmic fluorescence (arrows) surrounds droplets which here appear empty but which in osmium-tetroxide post-fixed material have been shown to contain lipid. Every cell exhibits some oCS-positive reactivity.

Fig. 2. Day-55 chorion incubated with oCS antiserum. A small amount of hormone is present in the apical (toward the embryo) ends of some uninucleate chorionic cells. The binucleate cell (bnc) in the top left corner shows no binding of oCS antiserum. $n=$ nucleus.

Fig. 3. Day-28 chorion incubated for localization of oCS. Four binucleate cells (bnc) are seen in cross-section: all are oCS-negative. Antibody binding is confined primarily to the apical ends of the uninucleate chorionic cells (arrows) and, again, in close proximity to lipid droplets. 


\section{PLATE 1}

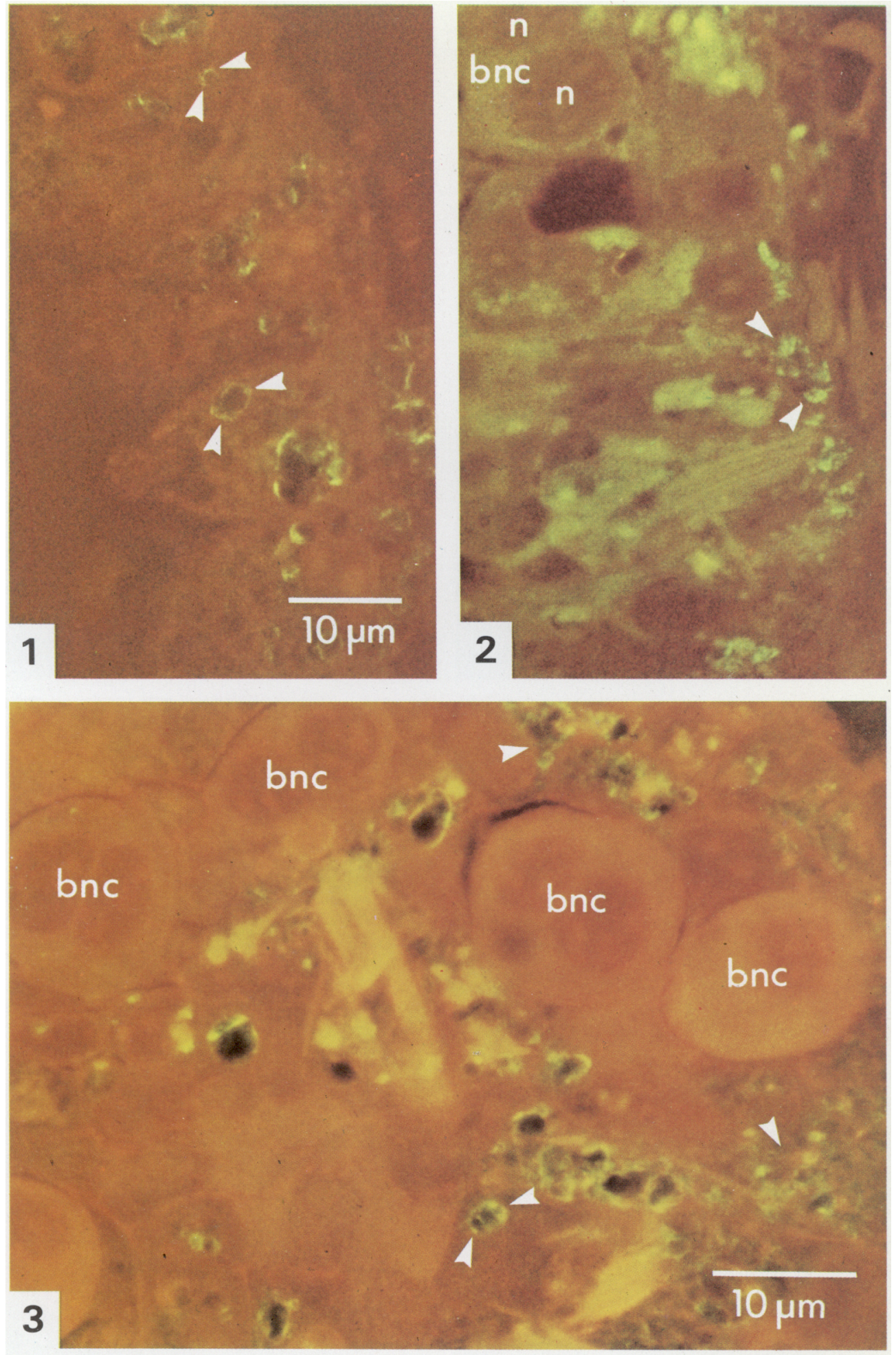

(Facing p. 10) 


\section{PLATE 2}
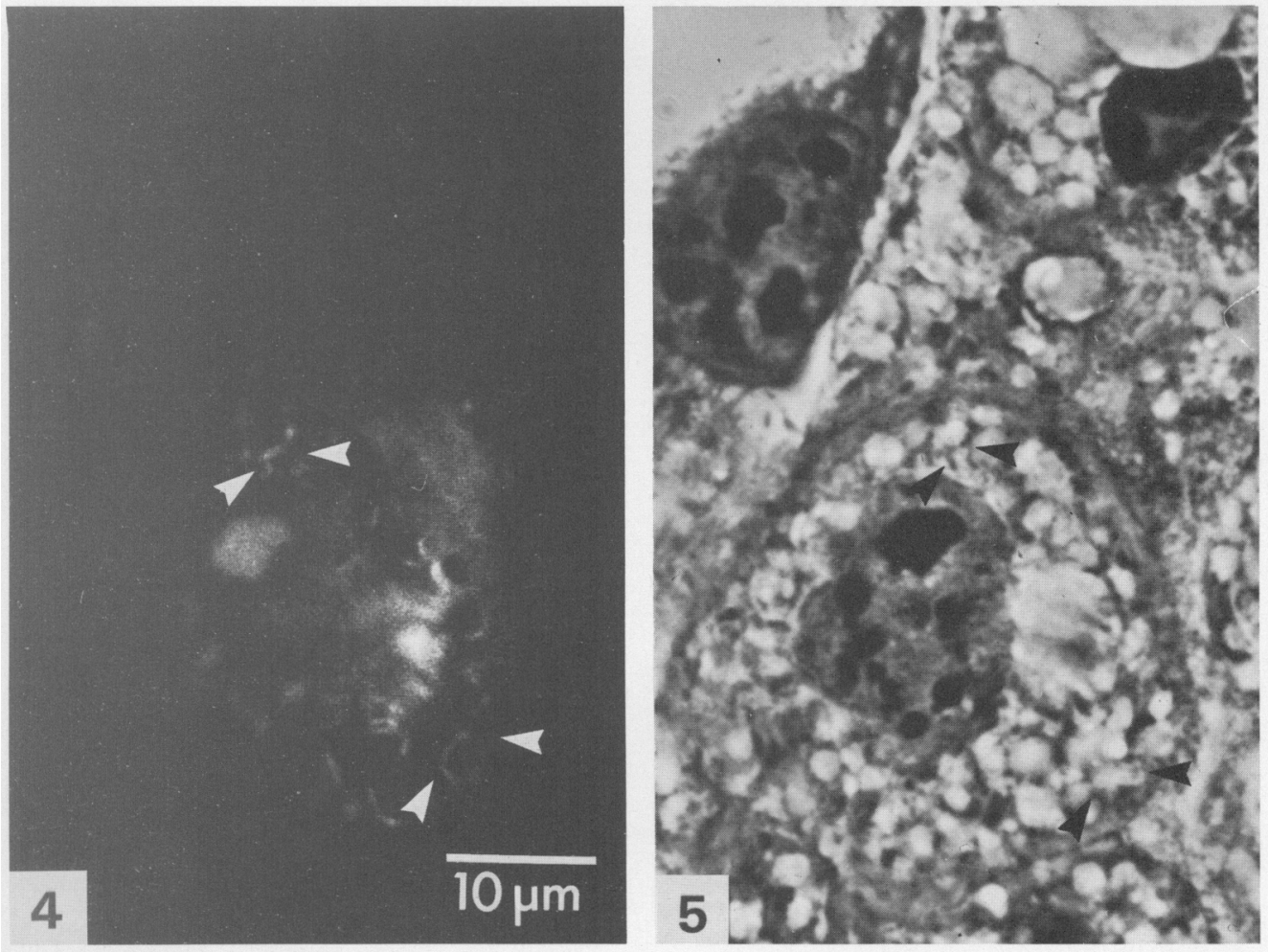

n

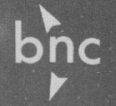

n

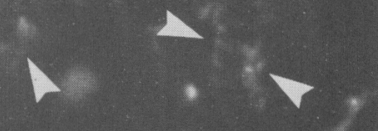

I

(2)

6
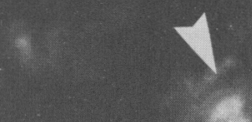

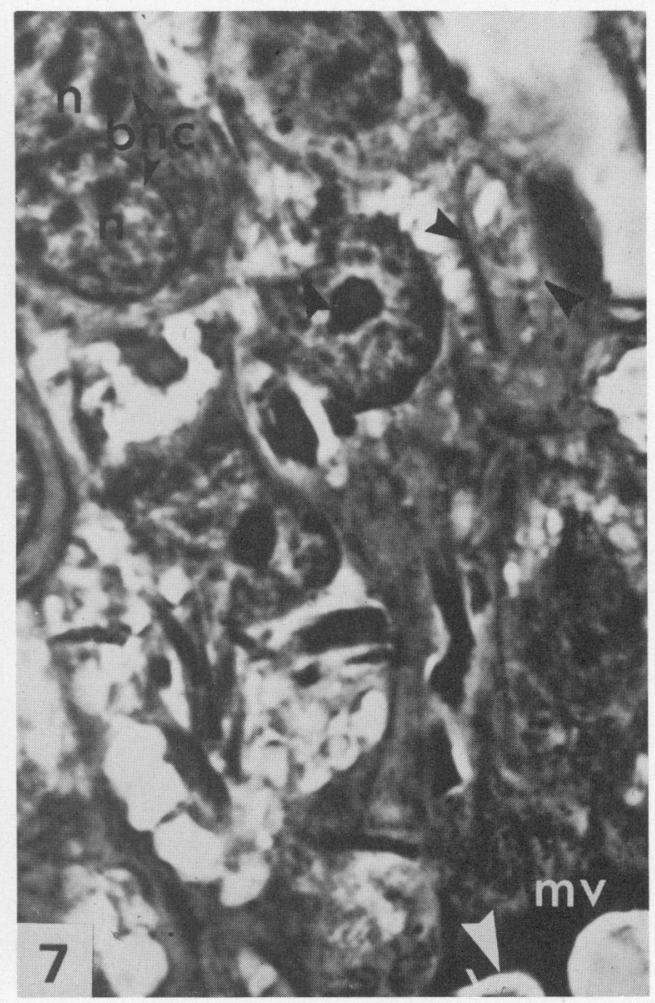


maternal caruncular epithelium and fixed and embedded in glycol methacrylate (Carnegie et al., 1980).

\section{Tissue sectioning and incubation}

Sections $(1-2 \mu \mathrm{m})$ were cut and attached to glass slides as previously described (Carnegie et al., 1980). For Day-12 samples, 4 and $6 \mu \mathrm{m}$ thick sections were also prepared in an effort to improve the detection of minute quantities of oCS, if present. The incubation procedures employing rabbit anti-oCS (Chan et al., 1978b) followed by fluorescein isothiocyanate (FITC)-labelled goat anti-rabbit $\gamma$-globulin have already been reported and always included a control slide exposed to the second antiserum alone (Carnegie et al., 1980). Before antigen localization, the yellow-green background fluorescence due to tissue fixation in glutaraldehyde was changed to red by preincubation of the sections in Schiff's reagent (Carnegie et al., 1980) so that the green fluorescence due to antibody binding was more easily seen.

\section{Microscopy and photomicrography}

Fluorescence was observed with a Carl Zeiss microscope equipped with an epifluorescence illuminator using an HBO 200 d.c. burner, an F1 beam splitter, exciter filter B612 and barrier filters 50 and 65 . Sections were also viewed with phase-contrast optics.

Fluorescence was recorded on Kodak High Speed Ektachrome $35 \mathrm{~mm}$ film, which was push-processed to $400 \mathrm{ASA}$ to accommodate the short exposure times required to capture the FITC fluorescence. Black and white micrographs were obtained by copying the slides on Kodak High Contrast Copy Film, using appropriate filters to decrease the intensity of the red background fluorescence. Phase-contrast images were recorded on Kodak Ektapan $4 \times 5$ inch sheet film.

\section{Radioimmunoassay}

At slaughter, the tissues were excised, immediately frozen in plastic bags over solid carbon dioxide and stored at $-20^{\circ} \mathrm{C}$ until required for assay. The estimation of oCS in fetal membranes and in maternal uterine tissue was carried out by a double-antibody radioimmunoassay

\section{PLATE 2}

The diffuse red background due to pretreatment of tissue sections with Schiff's reagent cannot be completely obliterated when copying colour slides on black and white film. The green fluorescence due to antibody binding appears as more intense white lines (arrows). Comparison with the colour plate helps to distinguish the two kinds of fluorescence in the black and white figures.

Fig. 4. Day-14 chorion incubated with oCS antiserum. Fluorescence due to antibody binding (arrows) is associated with lipid droplets in the chorionic cytoplasm. The endodermal cell in the top left corner (fluorescence of nucleoli due to Schiff's reagent is just visible) is oCS-negative. The embryo is toward the upper left and the maternal epithelium is toward the lower right.

Fig. 5. Identical region to that in Fig. 4, stained with $1 \%$ aqueous acid fuchsin. Arrows correspond to those in Fig. 4. Phase-contrast optics.

Fig. 6. Day-28 chorion incubated for localization of oCS. Several areas (small arrows) of oCS-reactivity are present in uninucleate chorionic cells. The binucleate cell (bnc) in the top left corner shows no binding of oCS antiserum. The large arrow indicates a region of strong Schiff's fluorescence in the maternal uterine tissue. $\mathrm{n}=$ nucleus.

Fig. 7. Same region as that shown in Fig. 6, stained with $1 \%$ aqueous acid fuchsin. Arrows correspond to those in Fig. 6. The microvilli $(\mathrm{mv})$ of the feto-maternal junction can be seen at the lower right. 
procedure which has a sensitivity of $1.0 \mathrm{ng} / \mathrm{ml}$ and intra-assay (10 measurements of oCS concentration in plasma from 3 pregnant sheep made in a single assay) and interassay (levels of oCS in plasma from 6 pregnant sheep determined 5 times in consecutive assays) coefficients of variation of $10.5 \%$ and $8.2 \%$, respectively (Chan et al., 1978b). It has also been previously demonstrated that ovine pituitary hormones and placental lactogens from the rat, goat, cow, monkey and human do not cross-react in this assay system at concentrations as high as 10 $\mu \mathrm{g} / \mathrm{ml}$ (Chan et al., 1978b).

\section{Results}

\section{Microscopy}

With the exception of samples taken at Day 12, oCS was detected in the chorionic layer at all stages examined. Repeated incubations of Day-12 trophoblast using 2, 4 and $6 \mu \mathrm{m}$ sections revealed no fluorescent staining attributable to antibody binding. The pattern of antibody distribution described previously for Days 20 and 28 (Carnegie et al., 1980) was observed at all of the remaining stages: fine lines of fluorescence in the cytoplasm of uninucleate cells, encircling phase-light spherical bodies roughly $2 \mu \mathrm{m}$ in diameter. These bodies, Sudan black B-positive in osmium tetroxide post-fixed material (Carnegie, 1980), are presumed to contain lipid. Maximal antibody binding was observed at Day 28, while at Days 14 and 55 the fluorescent staining was noticeably reduced, indicating the presence of lower levels of hormone.

At Days 14 and 16, oCS distribution was fairly uniform throughout the single layer of chorionic cells. A survey of Day-14 tissue revealed various intensities of fluorescence in the cytoplasm of every chorionic cell (Pl. 1, Fig. 1); only the inner lining of endodermal cells was negative (Pl. 2, Figs 4 and 5). There were no binucleate cells present at this stage. The situation was little changed by Day 16; only the occasional oCS-negative cell was seen. By Day 28, oCS distribution had become quite localized: rounded binucleate cells were easily distinguished from their columnar, uninucleate neighbours, not only on the basis of structural differences, but also because they were consistently oCS-negative (Pl. 1, Fig. 3; Pl. 2, Figs 6 and 7). Often, the cytoplasm of uninucleate cells in the immediate vicinity of the binucleates was oCS-positive (Pl. 1, Fig. 3; Pl. 2, Figs 6 and 7), but antibody binding was never observed within the confines of the binucleate cell plasma membranes.

Only certain of the uninucleate chorionic cells were oCS-positive on Day 28. At this time, the surface of the maternal caruncle is no longer smooth but is raised into numerous villi. The chorionic cells overlying the tips of the maternal villi are taller than those reaching into the crypts and their swollen apical ends are filled with lipid droplets, interspersed with occasional crystals (Carnegie, 1980). It was here that most of the antibody binding occurred, the fluorescent lines emphasizing the boundaries of the droplets (P1. 1, Fig. 3). Occasionally, cells in other regions of the chorion, running parallel to the caruncular surface or extending partly into a crypt, also contained oCS and, again, the fluorescent staining always surrounded lipid droplets.

The distribution of oCS was the same at Day 55, although the tissue concentrations of hormone were markedly reduced. Binucleate cells were still present and always oCS-negative (Pl. 1, Fig. 2). Groups of 2-4 uninucleate cells contained small cytoplasmic regions of antibody binding, again outlining small phase-light bodies presumed to be lipid droplets. A survey of a large area of chorion indicated that, on the average, about 1 cell in 50 contained oCS (as opposed to roughly 1 cell in 4 at Day 28 ).

\section{Radioimmunoassay}

The concentrations of oCS in fetal tissues and in maternal uterine tissues are shown in Tables 1 and 2. The oCS was detectable in chorionic tissue from Day 16 and in maternal uterine 
Table 1. The concentration of oCS ( $\mathrm{ng} / \mathrm{g}$ fresh weight) in fetal membranes at different stages of gestation

\begin{tabular}{cccc}
\hline $\begin{array}{c}\text { Day of } \\
\text { gestation }\end{array}$ & Chorion & Allantois & Chorio-allantois \\
\hline 16 & 50 & & \\
18 & $96,60,<10$ & & \\
20 & $300,90,<10$ & $16,<10$ & \\
22 & & & $281,259,183,126$ \\
25 & & & 204 \\
81 & & & 360 \\
\hline
\end{tabular}

Table 2. The concentration of oCS (ng/g fresh weight) in maternal endometrium

\begin{tabular}{ccc}
\hline $\begin{array}{c}\text { Day of } \\
\text { gestation }\end{array}$ & Caruncles & Inter-caruncular tissue \\
\hline 16 & $<10,<10$ & $74,<10$ \\
18 & $43,65,23$ & $111,160,11$ \\
20 & $<10,36,39,48,39$ & 43,40 \\
22 & $96,71,79,74$ & \\
\hline
\end{tabular}

tissue from Day 18. There was insufficient fetal tissue available to test for the presence of oCS before Day 16 and due to difficulties in separating membranes, particularly in the early stages, sufficient membrane tissue was not always available for assay.

\section{Discussion}

The immunolocalization of oCS at various stages of gestation has been reported several times over the past few years by three separate groups. Different localization results have been obtained by each group and comparison is rendered difficult in that the fixation and embedding techniques employed were all different.

Initial studies were focussed on late pregnancy. Martal et al. (1977) found that their anti-oCS preparation was bound exclusively to the large periodic acid-Schiff (PAS)-positive mono- or binucleate cells of the trophoblast, while the antiserum used by Reddy \& Watkins $(1978 \mathrm{~b})$, in addition to labelling the PAS-positive binucleate cells, was also bound to uninucleate trophoblastic cells which did not appear to be PAS-reactive. In a subsequent study which was extended to include Day 22 of gestation, it was found that not all binucleate cells interacted with the oCS antiserum and Watkins \& Reddy (1980) proposed the existence of 2 types of trophoblastic binucleate cells: those involved in the production of oCS and those responsible for the elaboration of some other secretory product. Uninucleate oCS-positive cells were reported to be present consistently in the maternal syncytium, rather than in trophoblast and Watkins \& Reddy (1980) postulated that they were either originally binucleate cells which had migrated across the feto-maternal junction or maternal cells which were themselves capable of oCS synthesis. In contrast, we have repeatedly found that anti-oCS binding is confined entirely to the uninucleate trophoblastic cells and is not a property of the PAS-positive binucleate cells.

The present study detected oCS as early as Day 14 and Martal \& Djiane (1977) reported that Day-16 blastocysts contain oCS. However, Watkins \& Reddy (1980) were unable to detect oCS using immunolocalization techniques earlier than Day 22 in sections of tissue fixed in Bouin's fluid and embedded in Paraplast. Two explanations for this discrepancy can be given. 
Before Day 22, when the levels of oCS are low, the amount of immunologically active antigen remaining in the tissue following the fixation and embedding procedures used by Watkins \& Reddy (1980) may have been below the sensitivity of the immunolocalization technique employed. Alternatively, the long fixation time ( 2 weeks) and high temperature required for Paraplast embedding may have completely destroyed the antigenicity of the oCS molecules and at the same time rendered some other tissue component capable of interaction with the oCS antiserum. Tissue fixation has been shown to have a tremendous effect on antigen-antibody interactions, not only by inactivating antigenic sites on a given molecule, but also by exposing other sites which were previously inaccessible to the antibody (Mabuchi \& Okuno, 1977; Nishino \& Watanabe, 1977). In the present study, it became evident that tissue fixed for $0.5 \mathrm{~h}$ in glutaraldehyde had to be maintained at low temperature throughout all subsequent treatments, including embedding, if antibody binding was to be obtained (Carnegie et al., 1980). It is possible, however, that the longer fixation procedures employed by Martal et al. (1977), Reddy \& Watkins (1978b) and Watkins \& Reddy (1980) provided enough extra protection for the oCS antigenic sites that they were able to withstand the higher temperature required for paraffin-wax embedding.

Assuming that tissue fixation and embedding are not responsible for the dissimilar findings, the only other factor which could account for these variations would be differences in antibody specificity (see Reddy \& Watkins, 1978a). The oCS antigens prepared by Chan et al. (1976) and Reddy \& Watkins (1978a) are very similar in a number of properties and both differ from that isolated by Martal \& Djiane (1975). Antisera which have been prepared for radioimmunoassay are often not adequate for specific antigen localization in tissue sections (Petrusz, Sar, Ordronneau \& Dimeo, 1976), but the oCS antisera were studied by Ouchterlony immunodiffusion (Martal et al., 1977; Carnegie et al., 1980) and preincubation of the antiserum with purified antigen (Martal et al., 1977; Reddy \& Watkins, 1978a; Carnegie, 1980).

One serious weakness with preincubation as a test of specificity is that the same antigen preparation is generally used to saturate the antibody molecules as was initially employed for antiserum production. Antigens are obtained from biological material and for this reason can never be considered 100\% pure (Swaab, Pool \& van Leeuwen, 1977). Hence, those impurities in the antigen preparation which had given rise to other populations of antibody molecules would still be present in the preincubated material and would saturate the non-specific antibodies in the antiserum preparation, producing a false positive test for antiserum specificity. An additional problem is that the large excess of antigen often required during preincubation to obtain significant blockage of staining is not always available. Sometimes, possibly because the configuration of the antigen immobilized in the tissue gives it a greater affinity for the antibody than that of the antigen in solution, even a very high concentration of antigen during the preincubation is not sufficient to abolish completely antibody binding to the tissue section (Zimmerman, Hsu, Ferin \& Kozlowski, 1974; Swaab \& Pool, 1975).

The Ouchterlony immunodiffusion tests have established that the antisera do bind purified oCS and that the preparation used by Martal et al. (1977) does not cross-react with human placental lactogen, human growth hormone, bovine growth hormone or ovine prolactin. However, certain questions remain which may be answered by modifications of this basic technique. Whole cell immunoelectrophoresis (Olden \& Yamada, 1977) would indicate the number of components in a given tissue capable of interaction with an antiserum preparation, but such data would have to be interpreted with caution. The same antigen-antibody interactions need not necessarily occur between an antiserum preparation and proteins obtained by fractionating fresh tissue as would take place with proteins which have been immobilized in a tissue section and denatured to some undetermined extent (Forer, 1978). One may have to resort to fractionating the cells and then fixing the separated components in the same manner as the tissue used for immunolocalization experiments before studying their immunological properties (Forer, 1978). 
Although the specificity of the oCS antiserum used for antigen localization in the present study has not been clearly established, certain facts suggest that it is indeed oCS which is being localized. Ouchterlony immunodiffusion tests have indicated that the antiserum does interact with purified oCS (Carnegie et al., 1980). The time of first detection of the hormone in this study (Day 14) correlates well with that determined by radioimmunoassay (Day 16) using either this antiserum preparation or that of Martal \& Djiane (1977). The sensitivity of the immunofluorescence method has not been determined, but it may well detect lower levels of oCS than is possible by radioimmunoassay of tissue extracts. The appearance of oCS only after Day 12, at about the time the blastocyst is transformed from a spherical body into a filamentous one, may have biological significance if one of the major roles of oCS in early pregnancy is to control growth of the embryo and water transport across embryonic membranes.

This paper is Animal Research Centre Contribution No. 1010.

\section{References}

Ashford, A.E., Allaway, W.G. \& McCully, M.E. (1972) Low temperature embedding in glycol methacrylate for enzyme histochemistry in plant and animal tissues. J. Histochem. Cytochem. 20, 986-990.

Carnegie, J.A. (1980) Studies on the early ovine conceptus: a combinèd ultrastructural and histochemical investigation of the Day 12 to 16 blastocyst and the immunofluorescent localization of ovine chorionic somatomammotropin in the Day 14 to 55 trophoblast. Ph.D. thesis, Carleton University, Ottawa.

Carnegie, J.A., Chan, J.S.D., Robertson, H.A., Friesen, H.G. \& McCully, M.E. (1977) Placental lactogen in the preattachment sheep embryo. J. Anim. Sci. 45 (Suppl. 1), 142, Abstr. 359.

Carnegie, J.A., McCully, M.E. \& Robertson, H.A. (1980) Embedment in glycol methacrylate at low temperature allows immunofluorescent localization of a labile tissue protein. J. Histochem. Cytochem. 28 , 308-310.

Chan, J.S.D., Robertson, H.A. \& Friesen, H.G. (1976) The purification and characterization of ovine placental lactogen. Endocrinology 98, 65-76.

Chan, J.S.D., Robertson, H.A. \& Friesen, H.G. (1978a) Distribution of binding sites for ovine placental lactogen in the sheep. Endocrinology 102, 632-640.

Chan, J.S.D., Robertson, H.A. \& Friesen, H.G. (1978b) Maternal and fetal concentrations of ovine placental lactogen measured by radioimmunoassay. Endocrinology 102, 1606-1613.

Denamur, R. \& Martinet, J. (1961) Effets de l'hypophysectomie et de la section de la tige pituitaire sur la gestation de la brebis. Annls Endocr. 22. 755-759.

Fellows, R.E., Bolander, F.F., Hurley, T.W. \& Handwerger, S. (1976) Isolation and characterization of bovine and ovine placental lactogen. In Growth Hormone and Related Peptides, pp. 315326. Eds A. Pecile \& E. Muller. Excerpta Medica Foundation, Amsterdam.
Forer, A. (1978) Chromosome movements during celldivision: possible involvement of actin filaments. In Nuclear Division in the Fungi, pp. 21-88. Ed. I. B. Heath. Academic Press, New York.

Forsyth, 1.A. (1972) Use of a rabbit mammary gland organ culture system to detect lactogenic activity in blood. In Lactogenic Hormones, pp. 151-167. Eds G. E. W. Wolstenholme \& J. Knight. Churchill Livingstone, Edinburgh.

Handwerger, S., Maurer, W.F., Barrett, J., Hurley, T.W. \& Fellows, R.E. (1974) Evidence for homology between ovine and human placental lactogens. Endocr. Res. Commun. 1, 403-413.

Handwerger, S., Fellows, R.E., Crenshaw, M.C., Hurley, T.W., Barrett, J. \& Maurer, W.F. (1976) Ovine placental lactogen: acute effects on intermediary metabolism in pregnant and non-pregnant sheep. $J$. Endocr. 69, 133-137.

Hurley, T.W., Grissom, F.E., Handwerger, S. \& Fellows, R.E. (1977a) Purification and partial characterization of the cyanogen bromide fragments of ovine placental lactogen. Biochemistry, N.Y. 16, 5605-5609.

Hurley, T.W., Handwerger, S. \& Fellows, R.E. (1977b) Isolation and structural characterization of ovine placental lactogen. Biochemistry, N.Y. 16, 55985604.

Kelly, P.A., Robertson, H.A. \& Friesen, H.G. (1974) Temporal pattern of placental lactogen and progesterone secretion in sheep. Nature, Lond. 248, 435-437.

Lillie, R.D. (1965) Histopathologic Technic and Practical Histochemistry, p. 664. McGraw-Hill, New York.

Mabuchi, I. \& Okuno, M. (1977) The effect of myosin antibody on the division of starfish blastomeres. $J$. Cell Biol. 74, 251-263.

Martal, J. \& Djiane, J. (1975) Purification of a lactogenic hormone in sheep placenta. Biochem. Biophys. Res. Commun. 65, 770-778. 
Martal, J. \& Djiane, J. (1977) The production of chorionic somatomammotrophin in sheep. J. Reprod. Fert. 49, 285-289.

Martal, J., Djiane, J. \& Dubois, M. (1977) Immunofluorescent localization of ovine placental lactogen. Cell Tiss. Res. 184, 427-433.

Nishino, Y. \& Watanabe, Y. (1977) Evidence suggesting the presence of common antigenic determinants between dynein and tubulin. Biochem. Biophys. Acta 493, 104-114.

Olden, K. \& Yamada, K.M. (1977) Direct detection of antigens in sodium dodecyl sulfate-polyacrylamide gels. Analyt. Biochem. 78, 483-490.

Pearse, A.G.E. (1980) Histochemistry, Theoretical and Applied, Vol. I. Preparative and Optical Technology, 4th edn. Churchill Livingstone, Edinburgh.

Petrusz, P., Sar, M., Ordronneau, P. \& Dimeo, P. (1976) Specificity in immunocytochemical staining. J. Histochem. Cytochem. 24, 1110-1112.

Reddy, S. \& Watkins, W.B. (1978a) Purification and some properties of ovine placental lactogen. $J$. Endocr. 78, 59-69.
Reddy, S. \& Watkins, W.B. (1978b) Immunofluorescence localization of ovine placental lactogen. J. Reprod. Fert. 52, 173-174.

Swaab, D.F. \& Pool, C.W. (1975) Specificity of oxytocin and vasopressin immunofluorescence. J. Endocr. 66, 263-272.

Swaab, D.F., Pool, C.W. \& van Leeuwen, F.W. (1977) Can specificity ever be proved in immunocytochemical staining? J. Histochem. Cytochem. 25 , 388-390.

Watkins, W.B. \& Reddy, S. (1980) Ovine placental lactogen in the cotyledonary and intercotyledonary placenta of the ewe. J. Reprod. Fert. 58, 411-414.

Zimmerman, E.A., Hsu, K.C., Ferin, M. \& Kozlowski, G.P. (1974) Localization of gonadotropin-releasing hormone (Gn-RH) in the hypothalamus of the mouse by immunoperoxidase technique. Endocrinology 95 , $1-8$. 